\title{
INSTYTUCJA MAŁŻEŃSTWA W PRAWIE KANONICZNYM
}

Małżeństwo jest związane z naturą człowieka - i zgodnie z nią ustanowione $^{1}$ - co sprawia, że należy do porządku prawa naturalnego. Przyjmuje się, że każda jednostka z natury jest zdolna do zawarcia związku małżeńskiego². Kanon 1058 Kodeksu Prawa Kanonicznego z 1983 r. ${ }^{3}$, dozwala na zawarcie małżeństwa wszystkim, którym prawo tego nie zabrania. Instytucja ta występuje we wszystkich kręgach społecznych i prawnych, stąd wiele czynników - nie tylko geograficznych, ale również kulturowych, religijnych i prawnych - wpływa na jego kształt, przesłanki zawarcia, obowiązki i prawa małżonków oraz dopuszczalność i niedopuszczalność jego zawarcia 4 .

\section{Pojęcie małżeństwa w prawie kanonicznym}

Małżeństwo w prawie kanonicznym jest określane jako matrimonium, pochodzące od dwóch wyrazów łacińskich: mater i munus, oznaczających

* Mgr lic., doktorant, Katolicki Uniwersytet Lubelski Jana Pawła II, aplikant adwokacki; e-mail: karp15156@gmail.com, ORCID ID: https:/ / orcid.org/0000-0002-3371-8575.

1 Zob. J. Hervada, Consideraciones sobre la noción de matrimonio, Persona y Derecho 1983, nr 10, s. 264.

2 Zob. S. Paździor, Przyczyny psychiczne niezdolności osoby do zawarcia matżeństwa w świetle kan.1095, Lublin 2009, s. 9.

3 Codex Iuris Canonici auctoritate Ioannis Pauli PP. promulgatus (25.01.1983 r.), Acta Apostolicae Sedis (dalej: AAS) 75(1983), pars II (dalej: KPK 1983).

4 Zob. K. Piasecki, Prawo małżeńskie, Warszawa 2011, s. 11 i nast. 
kolejno: matkę i obowiązek ${ }^{5}$ Jak się wskazuje, jest to podkreślenie pozycji matki w rodzinie i jej najważniejszej roli w procesie wychowywania dzieci ${ }^{6}$. Poprzez małżeństwo powstaje rodzina, podstawowa forma życia społecznego, której nie sposób zastąpić, ponieważ jest pierwotną i samodzielną grupą społeczną, która pojawiała się w każdej fazie rozwoju cywilizacyjnego ${ }^{7}$. Rodzina realizuje funkcje pożądane, nie tylko z punktu widzenia samych małżonków, ale również istotne dla państwa ${ }^{8}$. Wedle J. Grześkowiaka, mimo iż związek małżeński zawierają dwie osoby na mocy wolnej od przymusu decyzji, nie jest on tylko tworem człowieka, ale pewną rzeczywistością nadaną z góry. Należy jednak pamiętać, że nadal pozostaje nierozerwalnie związany z egzystencją człowieka9 .

Pierwszą definicję matrimonium wypracowano w prawie rzymskim ${ }^{10}$. Jednakże rzymscy prawnicy na określenie małżeństwa używali również terminu nuptiae, a stworzyli dwie definicje tej instytucji. Pierwsza - justyniańska - określała mianem małżeństwa, związek kobiety i mężczyzny, który miał obejmować wspólnotę życia charakteryzującą się niepodzielnością. Drugą definicję, stworzył Modestinus, wedle którego małżeństwo jest związkiem kobiety i mężczyzny, będący połączeniem na całe ich życie i konstytuującym współudział w prawach ludzkich i boskich ${ }^{11}$. Prawo rzymskie regulowało kwestie małżeńskie jedynie w niezbędnym minimum. Nie sam akt zawarcia statuował istnienie małżeństwa, ale faktyczne pozostawanie we wspólnocie małżeńskiej i wola utrzymywania tej wspólnoty ${ }^{12}$. Mimo iż instytucja małżeństwa miała charakter bardziej społeczny, została jednak uznana przez prawo i wywodzono z niej skutki prawne ${ }^{13}$. Za consensus małżeński uważano fakt podjęcia pożycia małżeńskiego, a małżeństwo trwało tak długo, jak trwała wspólnota

5 Zob. T. Pawluk, Prawo Kanoniczne wedtug Kodeksu Jana Pawła II, t 3. Prawo małżeńskie, Olsztyn 1984, s. 15.

6 Zob. tamże.

7 Zob. W. Góralski, Iusconnubii. Ochrona i ograniczenia w prawie międzynarodowym, polskim i kanonicznym, red. W. Góralski, Płock 2016, s. 5.

8 Zob. T. Smyczyński, Prawo rodzinne i opiekuńcze. Analiza i wykładnia, Warszawa 2001, s. 38.

9 Zob. J. Grześkowiak, „Tajemnica to jest wielka”. Sakramentalne przymierze matżeńskie, Opole 2010, s. 5.

10 Zob. W. Rozwadowski, Prawo rzymskie. Zarys wykładu wraz z wyborem źródet, Poznań 1992, s. 203-204.

11 Zob. K. Kolańczyk, Prawo rzymskie, Warszawa 2007, s. 223.

12 Zob. S. Paździor, Przyczyny psychiczne niezdolności..., s. 10.

13 Zob. M. Kuryłowicz, Prawo i obyczaje w starożytnym Rzymie, Lublin 1984, s. 54 i nast. 
małżeńska i tak długo, jak sami małżonkowie mieli zamiar wzajemnego małżeńskiego pożycia, a nie pojawiały się żadne zakazy prawne ${ }^{14}$.

Mimo wielu zmian cywilizacyjnych na przestrzeni wieków małżeństwo zawsze posiadało swój wymiar religijny. Było jednak w różny sposób przeżywane i rozumiane. Magisterium Kościoła, na pytanie o pochodzenie instytucji małżeństwa, udziela jednoznacznej odpowiedzi - jest ono dziełem Boga ${ }^{15}$. Zgodnie z chrześcijańską koncepcją, uznaje się je za znak przymierza z narodem wybranym, mającym opierać się na zgodzie małżeńskiej, miłości i wzajemnej pomocy małżonków. Także nauka Jezusa Chrystusa potwierdza biblijną wizję małżeństwa, będącego związkiem jednego mężczyzny i jednej kobiety, ustanowionego przez Stwórcę. Natomiast św. Paweł skłania się ku małżeństwu jako więzi Kościoła z samym Chrystusem $^{16}$. Mimo dwóch skrajnych tendencji spostrzegania małżeństwa, Ojcowie Kościoła uważali je za moralnie dobre. Należy uznać, iż największymi zasługami dla nauki katolickiej o małżeństwie wykazał się św. Augustyn. To w okresie od XI do końca XVI w., teologowie i kanoniści stworzyli pojęcie tzw. umowy konsensualnej, charakteryzującej się ujawnieniem woli kontrahentów, którzy zawierali związek małżeński ${ }^{17}$. Wtedy to samo zagadnienie konsensu małżeńskiego znalazło się w obrębie ich największego zainteresowania ${ }^{18}$. Czasy nowożytne i Sobór Trydencki zapewniły doniosłą definicję sakramentalności małżeństwa, czego skutkiem było nakazanie zawierania małżeństw w formie kanonicznej, głównie celem zapobieżenia zawieraniu małżeństw tajnych. Kolejnym krokiem, było podkreślenie przez papieża Leona XIII ${ }^{19}$ sakralnej istoty małżeństwa i najwyższej kościelnej nad nim jurysdykcji. To stanowisko uzyskało wydźwięk również w Kodeksie Prawa Kanonicznego z 1917 r. ${ }^{20}$, a także

14 Zob. W. Rozwadowski, Prawo rzymskie. Zarys wykładu wraz z wyborem źródet, Poznań 1992, s. 206.

15 Zob. A. Miralles, Ilmatrimonio. Teologia e vita, Roma 1996, s. 13.

16 Zob. W. Góralski, Kanoniczne prawo małżeńskie, Warszawa 2000, s. 19.

17 Zob. S. Paździor, Przyczyny psychiczne niezdolności..., s. 7.

18 Zob. W. Góralski, Kanoniczne prawo matżeńskie, s. 19.

19 Leon XIII, „Arcanum divinae sapientiae”. O matżeństwie chrześcijańskim (1880 r.), AAS 12(1920); tekst polski: http://henryklahola.nazory.cz/LEO13ADS1880PL.htm [dostęp: 9.01.2019 r.].

20 Codex Iuris Canonici Pii X Pontificis Maximi iussu digestus Benedicti Papae XV auctoritate promulgates (27.05.1917 r.), AAS 9(1917), pars II (dalej: KPK 1917). 
encyklice Piusa $\mathrm{XI}^{21}$, w której papież odniósł się do dotychczasowej nauki Kościoła o instytucji małżeństwa. Podkreślił przede wszystkim wartość osobowej unii małżeńskiej oraz małżeńskiej miłości ${ }^{22}$. Ustawodawca w KPK 1917 ujął małżeństwo w sposób ściśle jurydyczny, pomijając jego charakter ludzki i duchowy. Ustanowił je kontraktem, poprzez który mężczyzna i kobieta oddają się sobie nawzajem i przyjmują określone prawa i obowiązki, pośród których istotnym jest ius in Corpus, czyli prawo do ciała, wyłączne i o trwałym charakterze, w powiązaniu z aktami skierowanymi do zrodzenia potomstwa. Wojciech Góralski zauważa, że koncepcja KPK 1917 skupiała się przede wszystkim na aspekcie biologiczno-prokreacyjnym małżeństwa, a za jego cel nadrzędny uznawała zrodzenie i wychowanie potomstwa, skupiając się dopiero w drugiej kolejności na wzajemnej pomocy małżonków oraz zaspokajaniu popędu ${ }^{23}$.

Sobór Watykański II stał się odpowiednią okazją do głębszej refleksji nad instytucją małżeństwa. Wskutek tych rozważań, istniejąca dotąd negatywna koncepcja małżeństwa, uznająca je za kontrakt, zaczęła być postrzegana jako niewystarczająca. Zarówno teologowie, jak i kanoniści dostrzegli wymiar osobowy małżeństwa oraz nowe płynące z niego wartości, dotąd niedostrzegane i przysłonięte przez sformalizowany i kontraktowy charakter. Jednakże, jak podkreśla W. Góralski, wskazanie na osobowy wymiar małżeństwa, w niektórych przypadkach doprowadziło również do zbyt skrajnego podkreślenia roli miłości małżeńskiej². W konsekwencji zaczęto pomijać rozumienie małżeństwa, jako więzi sprawiedliwości, polegającej na wzajemnym przekazywaniu sobie obowiązków i praw małżeńskich ${ }^{25}$.

Głównym skutkiem tych refleksji, była nauka soboru zawarta w konstytucji duszpasterskiej o Kościele Gaudium et spes ${ }^{26}$. Przede wszystkim, odmiennie do umownej koncepcji małżeństwa, zauważono, że jest ono

21 Pius XI, Encyklika o małżeństwie chrześcijańskim "Casticonubi”(31.12.1930 r.), AAS 22(1930) 543; tekst polski: serwis internetowy Opoka, https:/ / opoka.org.pl/biblioteka/W/ WP/pius_xi/encykliki/casti_connubi_31121930.html [dostęp: 9.01.2019 r.].

22 Zob. W. Góralski, Kanoniczne prawo matżeńskie, s. 20.

23 Tamże.

24 Zob. tamże, s. 21.

25 Zob. P.J. Viladrich, Agonia del matrimonio legal. Una introducciõn a los elementos conceptuales bãsicos del matrimonio, Pamplona 1984, s. 153-161.

26 Sobór Watykański II, Konstytucja duszpasterska o Kościele w świecie współczesnym "Gaudium et spes" (7.12.1965 r.), AAS 58(1966). 
„głęboką wspólnotą życia i miłości małżeńskiej”27, zatem podkreślony został jego personalistyczny charakter. Nauka soborowa stała się słuszną inspiracją dla ustawodawstwa małżeńskiego, zawartego w Kodeksie Prawa Kanonicznego z 1983 r. ${ }^{28}$

\section{Rodzaje małżeństw}

W pierwszej kolejności można podzielić małżeństwa na ważne i nieważne, jeśli uwzględni się jego przedmiotowe skutki. Małżeństwo będzie uznawane za ważne (matrimonium validum), jeżeli między małżonkami zaistnieje węzeł małżeński. Taki stan rzeczy, będzie miał miejsce, jeśli nie wystąpią żadne małżeńskie przeszkody zrywające, a zgoda małżeńska zostanie wyrażona prawdziwie, przy zachowaniu formy przewidzianej prawem. Inaczej małżeństwo będzie nieważne (matrimoniu minvalidum). Mimo że małżeństwo nieważne posiada zewnętrzną formę małżeństwa, nosi miano małżeństwa pozornie rzeczywistego, co oznacza, że nie powstaje węzeł małżeński ${ }^{29}$. Jeśli małżeństwo zawarte nieważnie, przynajmniej jedna ze stron zawierała w dobrej wierze, zachowując formę przepisaną prawem, małżeństwo takie określa się mianem małżeństwa domniemanego (matrimonium putativum), dopóki oboje małżonkowie nie dowiedzą się o jego nieważności. Należy mieć na uwadze, że małżeństwo domniemane cieszy się przychylnością prawa, co oznacza, że na zewnątrz jest postrzegane jako ważne, a dzieci $\mathrm{z}$ niego zrodzone są uważane za dzieci ślubne ${ }^{30}$. Natomiast małżeństwo, które zawarte zostało nieważnie, w złej wierze przez jedną ze stron, nazywa się małżeństwem usiłowanym (matrimonium attentatum). Należy jednak je odróżnić od konkubinatu, który jest związkiem mężczyzny i kobiety, na wzór małżeństwa, jednak bez elementu zawarcia związku małżeńskiego ${ }^{31}$.

Można ponadto wyróżnić małżeństwa ważne zwyczajnie i małżeństwa uważnione (matrimonium convalidatum). Jeśli małżeństwo jest ważne

27 Tamże, 48.

28 Codex Iuris Canonici auctoritate Ioannis Pauli PP. promulgatus (25.01.1983 r.), AAS 75(1983), pars II; W. Góralski, Kanoniczne prawo małżeńskie, s. 22-23.

29 Zob. T. Pawluk, Prawo Kanoniczne wedtug Kodeksu Jana Pawła II, t. 3, s. 74.

30 Kan. 1137, kan. 1139 KPK 1983.

31 Kan. 1093 KPK 1983. 
zwyczajnie, to węzeł małżeński powstał w chwili wyrażenia zgody małżeńskiej przez strony. W sytuacji powstania małżeństwa uważnionego węzeł małżeński powstaje z chwilą jego uważnienia. Istnieje możliwość uważnienia małżeństwa na sposób zwyczajny, czyli powtórzenie przysięgi małżeńskiej, po usunięciu przeszkody, bądź na sposób nadzwyczajny, czyli uzdrowienie w zawiązku. Uzdrowienie w zawiązku mieści $\mathrm{w}$ sobie dyspensę od ponowienia przysięgi małżeńskiej i przeszkody, która ewentualnie wystąpiła oraz cofa skutki do momentu zawarcia małżeństwa.

Z uwagi na możliwość uzyskania dyspensy od małżeństwa, ustawodawca kościelny rozróżnił małżeństwo dopełnione i niedopełnione ${ }^{32}$. Małżeństwo dopełnione (matrimonium consummatum) to małżeństwo zawarte ważnie i dopełnione fizycznym pożyciem na sposób aktu ludzkiego, czyli dobrowolnym i świadomym. Takie małżeństwo zwykło się określać mianem małżeństwa zawartego i dopełnionego (matrimonium ratum et consummatum). Małżeństwo niedopełnione (matrimonium non consummatum) jest małżeństwem zawartym ważnie, jednak niedopełnione fizycznym aktem małżeńskim, zmierzającym do zrodzenia potomstwa. Takie małżeństwo zwykło się nazywać małżeństwem zwartym a niedopełnionym (matrimonium ratum et non cosummatum). Może zostać ono rozwiązane poprzez uzyskanie papieskiej dyspensy ${ }^{33}$, natomiast małżeństwo ważnie zawarte i dopełnione - tylko przez śmierć jednego z małżonków ${ }^{34}$.

Tadeusz Pawluk szczegółowo wyróżnia również inne rodzaje małżeństwa, wskazując na zawarte godziwie i niegodziwie. Małżeństwem zawartym godziwie określa małżeństwo, zawarte ważnie i z poszanowaniem wszelkich wymogów przepisanych prawem, niegodziwym natomiast - zawarte z poszanowaniem przepisów dotyczących jego ważności, ale z pominięciem pozostałych przepisów prawa małżeńskiego. Kolejno, małżeństwo publiczne - zawarte $\mathrm{w}$ warunkach gwarantujących mu pełną jawność oraz małżeństwo tajne - zawierane bez podawania do wiadomości czasu i miejsca ślubu oraz z pominięciem głoszenia zapowiedzi. Ostatnim rodzajem są małżeństwa religijne - zawierane wobec Kościoła, z poszanowaniem przepisów prawa kanonicznego i małżeństwa cywilne

\footnotetext{
32 Zob. W. Góralski, Kanoniczne prawo matżeńskie, s. 28.

33 Kan. 1142 KPK 1983.

34 Kan. 1141 KPK 1983.
} 
- zawierane przed urzędnikiem Urzędu Stanu Cywilnego, zgodnie z przepisami prawa państwowego ${ }^{35}$.

\section{Cele małżeństwa}

Zagadnienie dotyczące celów małżeństwa jest dość skomplikowane, z uwagi na różniące się podejście do niego w kolejnych wiekach. Zagadnieniem tym zajmowało się wielu uczonych, prócz św. Augustyna także P. Lombard, P. Abelard czy św. Tomasz ${ }^{36}$. Wspomniany św. Augustyn wskazał trzy dobra małżeństwa: bonum prolis mający zagwarantować trwałość rodzajowi ludzkiemu, bonum fidei, które miał zapewnić małżeństwu trwałość i bonum sacramenti, czyli nierozerwalność małżeństwa, która również jest gwarantem jego trwałości i swoistą rękojmią ładu społecznego ${ }^{37}$. Jednakże tylko dobro potomstwa było celem małżeństwa uważanym za nadrzędny. Nauka św. Augustyna zainspirowała wielu średniowiecznych teologów, według których najistotniejszym celem małżeństwa nie było zrodzenie potomstwa, ale zaspokajanie pożądliwości w pożyciu zgodnym i uporządkowanym ${ }^{38}$. Największy wkład w rozwój zagadnienia celów małżeństwa należy przyznać św. Tomaszowi, który nadał znaczenie teorii św. Augustyna. Uznał on za cel pierwszorzędny zrodzenie potomstwa, natomiast jako drugorzędny - pomoc małżonków w służbie rodzinie. Zaznaczył również, że cel drugorzędny jest podporządkowany pierwszorzędnemu ${ }^{39}$.

Jak zostało podkreślone $\mathrm{w}$ niniejszej pracy, okres od promulgacji KPK 1917 do Soboru Watykańskiego II, był czasem pogłębionej refleksji kanonistów i teologów nad instytucją małżeństwa. Stało się tak przede wszystkim ze względu na rozwój koncepcji personalistycznej, na którą odpowiedź przygotował papież Pius XI, wydając kolejno encykliki

35 Zob. T. Pawluk, Prawo Kanoniczne wedtug Kodeksu Jana Pawła II, t. 3, s. 76.

${ }^{36}$ Zob. M. Pogorzelska, Cele matżeństwa $w$ doktrynie $i$ w prawie kanonicznym, Studia Teologiczne 2014, t. 32, s. 425.

37 Św. Augustyn, De Genesci ad litteram imperfectus liber, 9, 7, 12, cyt. za: S. Paździor, Przyczyny psychiczne niezdolności..., s. 24.

38 Zob. Hugo a S. Victorio, Summa Sententiarum: tractatus VII. De sacramento coniugali, PL 176, s. 153-168.

39 Zob. S. Thomas, Summa Theologiae, Suppl., q. 41. a.1, cyt. za: M. Pogorzelska, Cele matżeństwa $w$ doktrynie..., s. 427. 
koncentrujące się na wskazaniach dotyczących realizacji celów małżeństwa ${ }^{40}$. Stwierdził, że zarówno małżeństwo, jak i jego cele, pochodzą od Boga, a tym nadrzędnym jest zrodzenie potomstwa, które traktowane jest $\mathrm{w}$ charakterze dobrodziejstwa i błogosławieństwa Bożego. Jako cel drugorzędny wskazał uśmierzanie pożądliwości, przypominając, że małżonkowie mają prawo do aktów małżeńskich zawsze, kiedy nastąpi przez nie realizacja przynajmniej jednego z celów małżeństwa i pod warunkiem ich prawidłowości ${ }^{41}$. Następnie zagadnieniem celów małżeństwa zajął się Sobór Watykański II. Postanowiono odejść od prokreacji jako celu pierwszorzędnego i skupiono się na postrzeganiu małżeństwa jako wspólnoty życia i miłości ${ }^{42}$. Można zatem wnioskować, że zastąpiono sferę miłości fizycznej, miłością całościową, w której integralna osoba jest zaangażowana $\mathrm{w}$ utworzenie relacji o charakterze niemal sakralnym, gdzie małżeństwo zostało podniesione do godności sakramentu ${ }^{43}$. Wynikiem tych rozważań, było wyodrębnienie celów małżeństwa w KPK 1983 i po raz pierwszy ich zrównanie. Analizując kan. 1055 § 1 KPK 1983 można zauważyć dwa cele wspólnoty małżeńskiej - dobro małżonków i dobro potomstwa.

\subsection{Dobro małżonków}

Jak zostało już podkreślone, Sobór Watykański II dostrzegł w małżeństwie różne dobra nadane wprost od Boga. Należy zatem pamiętać, że nierozerwalny charakter małżeństwa i dobro wspólnego potomstwa obligują do tego, aby miłość między małżonkami była odpowiednio wyrażana i miała szansę dojrzeć. Stąd też małżeństwo musi trwać jako wspólnota całego życia, nawet mimo braku potomstwa ${ }^{44}$. W tym stwierdzeniu zamyka się zamysł ustawodawcy, że wspólnota małżeńska z natury jest

40 Pius XI, "Divini Illius Magistri”. O chrześcijańskim wychowaniu młodzieży (1929 r.), AAS 22(1930); tekst polski: serwis internetowy eKai, https:/ / ekai.pl/dokumenty/encyklika-divini-illius-magistri/ [dostęp: 9.01.2019 r.].

41 Zob. Pius XI, Encyklika o małżeństwie chrześcijańskim "Casti conubi” (31.12.1930 r.), AAS 22(1930).

42 Zob. G. Leszczyński, Pojęcie "bonum coniugum” w prawie małżeńskim Kościoła, Śląskie Studia Historyczno-Teologiczne 2003, t. 36, z. 1, s. 109.

43 Zob. tamże, s. 110.

${ }_{44}$ Zob. Sobór Watykański II, Konstytucja duszpasterska o Kościele w świecie wspótczesnym "Gaudium et spes", 50. 
nakierowana na dobro małżonków ${ }^{45}$. Według Stwórcy prawdziwym dobrem małżonków jest ich dojrzewanie przez całe życie, dojrzewanie do zbawienia, do którego zostali stworzeni ${ }^{46}$. Zachowanie przymierza małżeńskiego, z poszanowaniem wierności, wytrwanie $\mathrm{w}$ tym przymierzu do końca życia, przyjęcie i wychowanie potomstwa prawdziwie służą dobru małżonków ${ }^{47}$. Pośród dóbr, jakie małżonkom przysparza wspólnota małżeńska, najważniejszym jest wzajemna pomoc, która, jak się wskazuje, posiada uzasadnienie biblijne. Ta wzajemna pomoc, ma obejmować wszystkie sfery wspólnego życia i nie może być w żaden sposób ograniczona. Wynika ona wprost z jedności małżeńskiej i ma być jej potwierdzeniem ${ }^{48}$.

\subsection{Dobro potomstwa}

Jak zostało już wspomniane, przełomowym dla szczegółowego określenia celów małżeństwa był Sobór Watykański II. Ojcowie soborowi postanowili odstąpić od jedynie prokreacyjnej i jurydycznej wizji małżeństwa ${ }^{49}$. Podkreślili również, że małżeństwo jest wspólnotą miłości, istniejącą tylko dzięki międzyosobowym więziom i darowi z siebie ${ }^{50}$. Odpowiedzią na soborową naukę jest KPK 1983, który w kan. 1055 § 1 podaje definicję małżeństwa jako przymierza, przez które kobieta i mężczyzna tworzą wspólnotę życia, skierowaną do zrodzenia i wychowania potomstwa. Małżeństwo jest przymierzem, którego uwieńczeniem jest posiadanie potomstwa ${ }^{51}$. Mężczyzna i kobieta oddają sobie wszystko - czym są i co ukazuje ich istotę - a wspólnota, którą tworzą, sama jest ukierunkowana na posiadanie potomstwa. Tego elementu ukierunkowania nie może zabraknąć w akcie woli, w momencie konstytuowania się małżeństwa. Stąd

45 Zob. T. Pawluk, Prawo Kanoniczne wedtug Kodeksu Jana Pawła II, t. 3, s. 51.

46 Zob. S. Paździor, Przyczyny psychiczne niezdolności..., s. 27.

47 Zob. W. Góralski, Pojęcie „bonum coniugum” (kan. 1055 § 1 KPK) w świetle orzecznictwa Roty Rzymskiej, Roczniki Nauk Prawnych 1996, t. 6.

48 Zob. T. Pawluk, Prawo Kanoniczne wedtug Kodeksu Jana Pawła II, t. 3, s. 51.

49 Zob. R. Wierzchanowski, Dobro potomstwa w kanonicznym prawie małżńskim. Próba syntezy, Tarnowskie Studia Teologiczne 2016, t. 35, nr 2, s. 63.

50 Zob. H. Stawniak, Wspólnotowy charakter matżeństwa w świetle nowego Kodeksu Prawa Kanonicznego, Prawo Kanoniczne 1988, t. 31, nr 3/4, s. 116.

51 Zob. R. Sobański, Symulacja częściowa w ujęciu k. 1086 § 2 a nauka o matżeństwie Konstytucji "Gaudium et spes", Śląskie Studia Historyczno-Teologiczne 1969, z. 2, s. 31. 
też ustawodawca nie może dozwolić, na wystąpienie sytuacji, w której nupturienci - wyrażając zgodę małżeńską - wykluczają to wszystko, co może prowadzić do zrodzenia potomstwa. Zaistnienie nieważności małżeństwa, łączy się z wewnętrznym brakiem nastawienia małżonków na posiadanie potomstwa i z nieprzekazaniem prawa do aktu małżeńskiego, poprzez który w zwykłych okolicznościach dochodzi do poczęcia i zrodzenia potomstwa ${ }^{52}$. Dziecko uznaje się za konsekwencję aktu ludzkiego, do którego każde z małżonków ma prawo, a to prawo jest $\mathrm{z}$ kolei konsekwencją wyrażenia zgody małżeńskiej ${ }^{53}$. Ukierunkowanie na posiadanie potomstwa, jako istotny element małżeństwa, jest częścią przedmiotu formalnego zgody małżeńskiej, która konstytuuje samo małżeństwo ${ }^{54}$. Zatem jeśli nupturienci w akcie zgody małżeńskiej, dopuszczają współżycie, a wykluczają posiadanie potomstwa - zawierają małżeństwo nieważnie. Nie istnieje możliwość połączenia dokonywania aktów małżeńskich z jednoczesnym działaniem mającym na celu przeciwdziałanie poczęciu potomstwa ${ }^{55}$. Wskazuje się, że akt małżeński niebędący wyrażeniem miłości do współmałżonka, ale jedynie wyrazem mniej szlachetnych pragnień, nie tylko obraża współmałżonka, ale również pozbawia poczęte potomstwo miłosnego przyjęcia ${ }^{56}$. Jak podkreślają przedstawiciele doktryny, ustawodawca nie miał na myśli jedynie zrodzenia potomstwa, ale w równym stopniu podkreślił obowiązek jego wychowania. Zatem nie jest ono dodatkiem do bonum prolis, ale jego nieodzowną częścią, a celem jest to, ażeby dziecko mogło się poprawnie rozwijać i włączyć do społeczeństwa. Wychowanie powinno obejmować takie kształtowanie osoby, które w odpowiedni sposób pozwoli się jej rozwinąć intelektualnie, społecznie, moralnie, religijnie i fizycznie. Wychowanie potomstwa jest prawem i obowiązkiem rodziców.

52 Zob. L. Świto, Exclusio boni prolis jako tytuł nieważności matżeństwa, Olsztyn 2003, s. 31.

53 Zob. R. Wierzchanowski, Dobro potomstwa..., s. 65.

54 Zob. H. Stawniak, Niemoc płciowa jako przeszkoda do matżeństwa. Ewolucja czy zmiana koncepcji?, Warszawa 2000, s. 343.

55 Kongregacja Nauki Wiary, Katechizm Kościoła Katolickiego, Poznań 1994, 2378, cyt. za: R. Wierzchanowski, Dobro potomstwa..., s. 67.

56 Zob. A. Günthör, Chiamata e risposta. Unanuova teologia morale, t. 1. Morale generale, Roma 1979, s. 689-690. 


\section{Istotne przymioty małżeństwa}

Do istotnych przymiotów małżeństwa należą: jedność i nierozerwalność. Jak podkreśla T. Pawluk, są to przymioty każdego małżeństwa, pod warunkiem jego ważnego zawarcia, ale w szczególny sposób dotyczą małżeństwa chrześcijańskiego, które nie jest jedynie umową, ale przede wszystkim sakramentem ${ }^{57}$.

\subsection{Jedność jako istotny przymiot małżeństwa}

Jedność małżeństwa, określana inaczej monogamią (gr. monogamia, od monós - jedyny, gámos - poślubienie ${ }^{58}$ ), polega na tym, że związek małżeński zawiera jeden mężczyzna i jedna kobieta. Monogamii przeciwstawia się poligamia równoczesna, gdy jeden z małżonków, za życia drugiego jest związany z wieloma mężami bądź żonami. Tak pojęta poligamia posiada dwie odmiany: poliandrię, gdy jedna kobieta żyje z wieloma mężczyznami oraz poligynię, w wypadku, kiedy jeden mężczyzna żyje z wieloma kobietami ${ }^{59}$. Jak podkreśla S. Paździor, jedność małżeństwa wynika z ludzkiej natury ${ }^{60}$. Potwierdzeniem tej tezy ma być fakt, że na świecie rodzi się podobna liczba dziewcząt i chłopców ${ }^{61}$. Także nauka Pisma Świętego wskazuje, że myśl Boża ustanowiła małżeństwo jako jedno i nierozerwalne. Mimo pojawienia się w Starym Testamencie praktyki posiadania dwóch żon, nierzadkim przypadkiem była jednak wierność tylko jednej małżonce. Także nauka Chrystusa potwierdza, że związek małżeński miał od samego początku charakter monogamiczny i takim powinien pozostać na zawsze ${ }^{62}$.

Prawo kanoniczne jednoznacznie wskazuje na monogamiczny charakter małżeństwa, zabraniając tym samym zawarcia drugiego związku małżeńskiego podczas trwania pierwszego. Jak podkreślił P. Gasparri, wedle teologów nierozerwalność jawiła się jako dobro sakramentu,

57 Kan. 1056 KPK 1983; T. Pawluk, Prawo Kanoniczne wedtug Kodeksu Jana Pawta II, t. 3, s. 15.

58 Monogamia, w: Stownik języka polskiego [online], https://sjp.pwn.pl/slowniki/monogamia.html [dostęp: 9.01.2019 r.].

59 Zob. T. Pawluk, Prawo Kanoniczne wedtug Kodeksu Jana Pawła II, t. 3, s. 31.

60 Zob. S. Paździor, Przyczyny psychiczne niezdolności..., s. 39.

61 Zob. E. Sztafrowski, Chrześcijańskie matżeństwo: pomoce prawno-pastoralne, Warszawa 1985, s. 14.

62 Zob. S. Paździor, Przyczyny psychiczne niezdolności..., s. 39. 
natomiast jedność jako dobro wiary, czyli wierność, która nakazuje spełnianie swoich małżeńskich obowiązków, niezawieranie innego małżeństwa, kiedy poprzednie jeszcze trwa i wstrzymanie się od współżycia $\mathrm{z}$ innymi osobami ${ }^{63}$.

Monogamiczny charakter małżeństwa wynika wprost z naturalnego uzupełniania się kobiety i mężczyzny, a także z samej ich woli dzielenia wspólnego życia ${ }^{64}$. Poligamia może doprowadzić przede wszystkim do zaprzestania spełniania przez małżeństwo swoich funkcji ${ }^{65}$ oraz do wykluczenia równości między małżonkami. Dzieje się tak, z uwagi na to, że podkreślana przez Sobór Watykański II wspólnota życia i miłości małżonków, nie może być realizowana w równym stopniu z wieloma partnerami czy partnerkami ${ }^{66}$. Trudności pojawiają się przede wszystkim w sferze życia rodzinnego i - jak trafnie zauważa S. Biskupski - może dostarczyć trudności w zrodzeniu potomstwa, ustaleniu ojcostwa oraz zaangażowaniu w wychowanie dzieci przez oboje małżonków ${ }^{67}$. Jednakże jedność małżeństwa odnosi się w najszerszym wymiarze do jedności węzła małżeńskiego. Oznacza to przede wszystkim jedność umowy małżeńskiej - jego cechę zewnętrzną, możliwą do spostrzeżenia ze społecznego punktu widzenia, jako związku dwóch osób. Polskie prawo nie dopuszcza żadnej z form poligamii, jednakże coraz powszechniejszym jest pozostawanie w związkach nieformalnych, często przez osoby, które w sensie prawnym są już związane, a kolejnego małżeństwa zawrzeć nie mogą. Stąd S. Paździor zadaje istotne pytanie odnośnie do istnienia możliwości zakwalifikowania takich związków jako swoistej formy poligamii faktycznej ${ }^{68}$.

\subsection{Nierozerwalność jako istotny przymiot małżeństwa}

Nierozerwalność bądź nierozwiązalność małżeństwa polega na tym, że związek małżeński nie może zostać zawarty na określony czas, ale

63 Zob. P. Gasparri, Tractatus canonicus de matrimonio, Paris 1904, s. 18-19, cyt. za:

S. Paździor, Przyczyny psychiczne niezdolności..., s. 39.

64 Zob. S. Paździor, Przyczyny psychiczne niezdolności..., s. 39.

65 Zob. T. Pawluk, Prawo Kanoniczne wedtug Kodeksu Jana Pawła II, t. 3, s. 32.

66 Zob. S. Paździor, Przyczyny psychiczne niezdolności..., s. 39-40.

67 Zob. S. Biskupski, Prawo małżeńskie kościoła rzymskokatolickiego, Warszawa 1956, s. 49.

68 Zob. S. Paździor, Przyczyny psychiczne niezdolności..., s. 40. 
dozgonnie, czyli do śmierci jednego z małżonków ${ }^{69}$. Jednak jak się wskazuje, nierozerwalność nie wynika wprost z praw przyrodzonych, które są oparciem rodziny oraz których niezachowanie będzie skutkować powstaniem zagrożenia dla społeczeństwa, z uwagi na to, że nierozerwalność jest postrzegana jako konsekwencja tych praw. Na tej podstawie, pojawia się wiele nieścisłości w poglądach, ponieważ nie wszyscy postrzegają nierozerwalność małżeństwa jako konieczną. Najsolidniejszym argumentem jest stwierdzenie, że dopuszczenie rozwodu i jego społeczna akceptacja nie jest w stanie zniszczyć życia rodzinnego i społecznego. Powołany argument często pojawia się w kontekście uznawania rozwodów w ustawodawstwach państwowych ${ }^{70}$.

Nierozerwalność może mieć dwie formy: wewnętrzną oraz zewnętrzną. Nierozerwalność wewnętrzna sprawia, że związek małżeński nie może zostać rozwiązany ani ze swojej natury, ani z upływem czasu, czy też jakiejś okoliczności następczej, ani też na skutek wzajemnej zgody stron. Samo pojęcie małżeństwa wskazuje nie tylko na jego trwałość, ale również dozgonność, które to dotyczą wszystkich małżeństw zawartych ważnie, a w szczególności tych sakramentalnych. Natomiast nierozerwalność zewnętrzna polega na tym, że węzła małżeńskiego nie można rozwiązać ani na mocy pozytywnego prawa Bożego, ani tym bardziej na podstawie prawa kościelnego bądź innego prawa ludzkiego. Nierozerwalność zewnętrzna posiada stopnie. Pierwszym jest nierozerwalność bezwzględna, którą cieszą się tylko małżeństwa chrześcijan, zawarte ważnie i dopełnione, które mogą być rozwiązane tylko w wypadku śmierci jednego z małżonków ${ }^{71}$. Kolejno niższy stopień obejmuje małżeństwa zawarte przez osoby ochrzczone oraz przez osobę ochrzczoną i nieochrzczoną, jeśli nie zostało dopełnione. Jego rozwiązanie jest możliwe poprzez uzyskanie dyspensy papieskiej na wniosek jednej lub obu stron przy zaistnieniu słusznej przyczyny $^{72}$. Natomiast małżeństwo osób nieochrzczonych zawarte ważnie, nawet dopełnione, może zostać rozwiązane na mocy przywileju wiary ${ }^{73}$.

69 Zob. W. Góralski, Kanoniczne prawo małżenskie, s. 31.

70 Zob. T. Pawluk, Przestanki nierozerwalności małżeństwa, Prawo Kanoniczne 1983, t. 26, nr 1/2, s. 221.

71 Kan. 1141 KPK 1983.

72 Kan. 1142 KPK 1983.

${ }^{73}$ Kan. 1143 § 1; kan. 1148 § 1; kan. 1149; kan. 1150 KPK 1983. 


\section{Małżeństwo jako sakrament}

Omawiając sakramentalny charakter małżeństwa, warto skupić się na samym pojęciu sakramentu. Wedle J. Grześkowiaka, sakrament jest istotnym aktem urzeczywistniania się Kościoła porównywanego często do dłoni Chrystusa, która to dotyka każdego chrześcijanina łaską sakramentalną. Sakramenty są ponadto symbolicznymi znakami Chrystusa i Kościoła, pokazują więź Chrystusa z Kościołem, jego hierarchiczny i wspólnotowy wymiar ${ }^{74}$.

Odnosząc się natomiast do małżeństwa - zgodnie z twierdzeniem T. Pawluka - należy uznać, iż posiada ono charakter sakramentalny tylko przez pochodzenie z prawa naturalnego, będącego realizacją woli Boga. Już pierwsi rodzice zostali złączeni węzłem małżeńskim, a jak wykazują szczegółowe badania, element sakralny występował w obrzędach zawierania małżeństwa już od najdawniejszych czasów. Nie był jednak źródłem nadprzyrodzonej łaski. Takim stało się dopiero małżeństwo Nowego Testamentu ${ }^{75}$. Podniesienie przez Chrystusa małżeństwa do godności sakramentu jest jednym z dogmatów wiary katolickiej. Z uwagi na brak w Ewangelii wspomnienia o momencie ustanowienia małżeństwa sakramentem, powstały na tym podłożu liczne spory. Jedni twierdzili, że do ustanowienia doszło podczas wesela w Kanie Galilejskiej (J 2,1-12), ponieważ Chrystus, pojawiając się na weselu, okazał szacunek instytucji małżeństwa. Inni podkreślali, że stało się to w czasie, kiedy Chrystus uznał pierwotną nierozerwalność małżeństwa (Mt 19,3-9), z uwagi na jego podobieństwo do nierozerwalnej komunii Chrystusa z Kościołem. Jeszcze inni upierali się, że do ustanowienia małżeństwa doszło, po 40 dniach od zmartwychwstania Chrystusa, który to ukazując się Apostołom, nauczał o Królestwie Bożym (Dz 1,3). Jednakże spór ten obecnie nie jest istotny, gdyż najistotniejszym jest założenie Kościoła przez Chrystusa, jako widzialnego znaku jego obecności w świecie ${ }^{76}$.

Sakramentalność małżeństwa jako dogmat została ogłoszona na Soborze Trydenckim, jednak mimo to od zawsze była przedmiotem nauczania Kościoła, z uwagi na jej zgodność z tradycją a postolską. O sakramentalności

74 Zob. J. Grześkowiak, "Tajemnica to jest wielka”..., s. 156.

75 Zob. T. Pawluk, Prawo Kanoniczne wedtug Kodeksu Jana Pawła II, t. 3, s. 23.

76 Zob. A. Skowronek, Ustanowienie sakramentów w akcie założenia Kościoła-prasakramentu, Ateneum Kapłańskie 1964, t. 67, s. 276-286. 
małżeństwa nauczał już św. Augustyn oraz papież Leon I Wielki. Kościół dojrzewał niejako do sakramentalności małżeństwa - stopniowo sobie ją uświadamiał poprzez doskonalsze odczytywanie woli i zamiaru Chrystusa, a samo małżeństwo zostało włączone w Jego zbawczą tajemnicę. Należy jednak nadmienić, że Jezus nie powoływał nowych rytów, lecz podejmował i nadawał nowy sens istniejącym już strukturom obrzędowym, które stanowiły rytualny wyraz relacji z Bogiem dla dawnych pokoleń ${ }^{77}$. Wspomniana już komunia Kościoła z Chrystusem, podobna do więzi małżeńskiej, została po raz pierwszy powołana przez św. Pawła w Liście do Efezjan. Potwierdzona przez Sobór Watykański II, definiujący małżeństwo jako przymierze zastępujące dawne kontraktowe określenie małżeństwa, ustanawiający małżeństwo wspólnotą życia i miłości, wspólnotą ducha dążącą do jedności z Chrystusem i świętości ${ }^{78}$.

Jako sakramentalne, uznaje się małżeństwo nie tylko katolików, ale każde małżeństwo zawarte przez osoby ochrzczone, o ile zostało zawarte ważnie. Od zawsze za nierozwiązywalny uważano węzeł małżeński powstały między ochrzczonymi niekatolikami. Nie będzie jednak uznawany za sakrament, związek małżeński, zawarty ważnie przez osoby nieochrzczone, z uwagi na ich niezdolność do przyjęcia żadnego, poza chrztem, sakramentu. Jednakże, kiedy małżonkowie przyjmą chrzest, ich małżeństwo uzyska status sakramentu. Dzieje się tak z uwagi na to, że intencja przyjęcia sakramentu małżeństwa zawiera się w intencji przyjęcie sakramentu chrztu. Nie wymaga się w takiej sytuacji ponowienia zgody małżeńskiej przez małżonków. Jak podaje T. Pawluk, większość komentatorów stoi na stanowisku, że sakramentem nie jest również małżeństwo osoby ochrzczonej z osobą nieochrzczoną, mimo nawet uzyskania odpowiedniej dyspensy od przeszkody różnej religii ${ }^{79}$.

77 Zob. J. Grześkowiak, „Tajemnica to jest wielka”..., s. 170.

78 Zob. S. Łupiński, Związek matżeński w wymiarze nadprzyrodzonym, w: Małżeństwo jedno i nierozerwalne. Argumenty prawa kanonicznego w orzekaniu o nieważności małżeństwa, red. R. Szewczyk, Ełk 2012, s. 80-81.

79 Zob. T. Pawluk, Prawo Kanoniczne wedtug Kodeksu Jana Pawła II, t. 3, s. 26. 


\section{Wnioski}

Małżeństwo jest związane z naturą człowieka, dlatego też należy do porządku prawa naturalnego oraz istnieje jako instytucja prawa we wszystkich kręgach społecznych i prawnych. Małżonkowie tworzą rodzinę, uznawaną za podstawową formę życia społecznego, która jest pierwotną i samodzielną grupą społeczną, pojawiającą się w każdej fazie rozwoju cywilizacyjnego. Ta rodzina, której początek upatruje się w małżeństwie, jest uznawana za pojęcie wieloaspektowe. Katechizm Kościoła Katolickiego przypominał o tym, iż małżeństwo legło u podstaw osoby, społeczności ludzkiej i chrześcijańskiej. Jak podkreślił, człowiek nadal spotyka się z tajemnicą stworzenia, w której zawiera się niezwykłe powołanie kobiety i mężczyzny do tworzenia szczególnej wspólnoty. Powołanie do małżeństwa i miłości staje się wrodzonym powołaniem każdego człowieka, skutkującym nie tylko fizycznym uzupełnieniem, ale również duchowym ubogaceniem obojga małżonków.

Analiza instytucji małżeństwa z punktu widzenia kanonistycznego ma za zadanie przypomnieć o wartości zakładanej rodziny i jej ogromnej roli w kształtowaniu każdego człowieka.

Słowa kluczowe: małżeństwo, prawo kanoniczne, cele małżeństwa, przymioty małżeństwa, jurysdykcja kościoła

\section{Bibliografia}

\section{Źródła prawa}

Codex Iuris Canonici Pii X Pontificis Maximi iussu digestus Benedicti Papae XV auctoritate promulgates (27.05.1917 r.), Acta Apostolicae Sedis 9(1917), pars II.

Codex Iuris Canonici auctoritate Ioannis Pauli PP. promulgatus (25.01.1983 r.), AAS 75(1983), pars II.

Leon XIII, „Arcanum divinae sapientiae”. O małżeństwie chrześcijańskim (1880 r.), AAS 12(1920); tekst polski: http://henryklahola.nazory.cz/LEO13ADS1880PL. htm [dostęp: 9.01.2019 r.].

Pius XI, „Divini Illius Magistri”. O chrześcijańskim wychowaniu młodzieży (1929 r.), AAS 22(1930); tekst polski: serwis internetowy eKai, https://ekai.pl/dokumenty/encyklika-divini-illius-magistri/ [dostęp: 9.01.2019 r.]. 
Pius XI, Encyklika o małżeństwie chrześcijańskim „Casti conubi” (31.12.1930 r.), AAS 22(1930) 543; tekst polski: serwis internetowy Opoka, https://opoka.org.pl/ biblioteka/W/WP/pius_xi/encykliki/casti_connubi_31121930.html [dostęp: 9.01.2019 r.].

Sobór Watykański II, Konstytucja duszpasterska o Kościele w świecie wspótczesnym "Gaudium et spes" (7.12.1965 r.), AAS 58(1966); tekst polski: Kościelne Prawo Publiczne. Wybór źródet, red. M. Sitarz i in., Lublin 2012.

Jan Paweł II, Adhortacja Apostolska o zadaniach rodziny chrześcijańskiej w świecie wspótczesnym "Familiaris consortio", AAS 74(1982) 19: tekst polski: serwis internetowy Opoka, https://opoka.org.pl/biblioteka/W/WP/jan_pawel_ii/ adhortacje/familiaris.html [dostęp: 9.01.2019 r.].

Kongregacja Nauki Wiary, Katechizm Kościoła Katolickiego, Poznań 1994.

\section{Literatura}

Biskupski S., Prawo małżeńskie kościoła rzymskokatolickiego, Warszawa 1956.

Gasparri P., Tractatus canonicus de matrimonio, Paris 1904.

Góralski W., Kanoniczne prawo małżeńskie, Warszawa 2000.

Góralski W., Pojęcie „bonum coniugum” (kan. 10555 § 1 KPK) w świetle orzecznictwa Roty Rzymskiej, Roczniki Nauk Prawnych 1996, t. 6.

Grześkowiak J., "Tajemnica to jest wielka”. Sakramentalne przymierze małżeńskie, Opole 2010.

Günthör A., Chiamata e risposta. Unanuova teologia morale, t. 1. Morale generale, Roma 1979.

Hervada J., Consideraciones sobre la noción de matrimonio, Persona y Derecho 1983, nr 10.

Hugo a S. Victorio, Summa Sententiarum: tractatus VII. De sacramento coniugali, PL 176, s. 153-176.

Iusconnubii - ochrona i ograniczenia w prawie międzynarodowym, polskim i kanonicznym, red. W. Góralski, Płock 2016.

Katechizm Kościoła katolickiego, Poznań 1994.

Kolańczyk K., Prawo rzymskie, Warszawa 2007.

Kuryłowicz M., Prawo i obyczaje w starożytnym Rzymie, Lublin 1984.

Leszczyński G., Pojęcie „bonum coniugum” w prawie małżeńskim Kościoła, Śląskie Studia Historyczno-Teologiczne 2003, t. 36, z. 1.

Łupiński S., Związek mał̇̇eński w wymiarze nadprzyrodzonym, w: Mał̇̇eństwo jedno i nierozerwalne. Argumenty prawa kanonicznego w orzekaniu o nieważności małżeństwa, red. R. Szewczyk, Ełk 2012.

Miralles A., Il matrimonio. Teologia e vita, Roma 1996.

Monogamia, w: Słownik Jezzyka Polskiego [online], https://sjp.pwn.pl/slowniki/ monogamia.html [dostęp: 9.01.2019 r.]. 
Pawluk T., Prawo Kanoniczne według Kodeksu Jana Pawła II, t. 3. Prawo małżéskie, Olsztyn 1984.

Pawluk T., Przesłanki nierozerwalności mał̇̇eństwa, Prawo Kanoniczne 1983, t. 26, nr $1 / 2$.

Paździor S., Przyczyny psychiczne niezdolności osoby do zawarcia małżeństwa w świetle kan. 1095, Lublin 2009.

Piasecki K., Prawo matżeńskie, Warszawa 2011.

Pogorzelska M., Cele matżeństwa w doktrynie i w prawie kanonicznym, Studia Teologiczne 2014, t. 32.

Rozwadowski W., Prawo rzymskie. Zarys wykładu wraz z wyborem źródeł, Poznań 1992.

Skowronek A., Ustanowienie sakramentów w akcie założenia Kościoła-prasakramentu,

Ateneum Kapłańskie 1964, t. 67.

Smyczyński T., Prawo rodzinne i opiekuńcze. Analiza i wykładnia, Warszawa 2001.

Sobański R., Symulacja częściowa w ujęciu k. 1086 § 2 a nauka o mał̇̇ństwie Konstytucji „Gaudium et spes”, Śląskie Studia Historyczno-Teologiczne 1969, z. 2.

Stawniak H., Niemoc ptciowa jako przeszkoda do matżeństwa. Ewolucja czy zmiana koncepcji?, Warszawa 2000.

Stawniak H., Wspólnotowy charakter małżenstwa w świetle nowego Kodeksu Prawa Kanonicznego, Prawo Kanoniczne 1988, t. 31, nr 3/4.

Sztafrowski E., Chrześcijańskie małżeństwo: pomoce prawno-pastoralne, Warszawa 1985. Św. Augustyn, De Genesi ad litteram imperfectus liber, PL 34.

Świto L., Exclusio boni prolis jako tytuł nieważności małżeństwa, Olsztyn 2003.

Tomasz z Akwinu, Suma teologiczna (I q.), tłum. P. Bełch i in., t. 1-34, Londyn 1962-1986.

Viladrich P.J., Agonia del matrimonio legal. Una introducciõn a los elementos conceptual esbãsicos del matrimonio, Pamplona 1984.

Wierzchanowski R., Dobro potomstwa w kanonicznym prawie małżéskim. Próba syntezy, Tarnowskie Studia Teologiczne 2016, t. 35, nr 2.

\section{INSTITUTION OF MARRIAGE IN CANON LAW}

\section{Sum mary}

Marriage is associated with the nature of man, therefore it belongs to the order of natural law and exists as an institution of law in all social and legal circles. Spouses form a family, recognised as the basic form of social life, which is a primary and independent social group that appears in every phase of civilisation development. This family, the beginning of which is seen in a marriage, is considered a multi-faceted concept. The Catechism of the Catholic Church reminded that marriage was at the heart of the person, human and Christian community. 
As it emphasises, man still encounters the mystery of creation, which includes the unusual calling of a man and woman to create a special community. The vocation to marriage and love becomes the innate calling of every human being, resulting in not only a physical complement, but also a spiritual enrichment of both spouses.

Analysing the institution of marriage from the canonical point of view, the task is to remind the value of family and its huge role in shaping every human being.

Key words: marriage, canon law, marriage purposes, marriage qualities, Church jurisdiction

\section{ИНСТИТУТ БРАКА В КАНОНИЧЕСКОМ ПРАВЕ}

\section{Резюме}

Брак связан с природой человека, поэтому относится к системе естественного права и существует как институт права во всех общественных и правовых кругах.

Супруги образуют семью, признанную в качестве основной формы социальной жизни, которая является основной и независимой социальной группой, возникающей на каждом этапе развития цивилизации. Эта семья, чье начало усматривается в браке, считается многоаспектным понятием. Катехизис Католической Церкви напоминал о том, что брак лег в основу личности, человеческого и христианского сообщества. Как подчеркнуто в Катехизисе, человек до сих пор сталкивается с тайной творения, в которой содержится необычайное призвание женщины и мужчины к созданию особого сообщества. Призвание к браку и любви становится врожденным призванием каждого человека, которое приводит не только к физическому дополнению, но и к духовному обогащению обоих супругов.

Анализ института брака с канонической точки зрения должен напомнить о ценности семьи, которую он основывает, и ее огромной роли в формировании каждого человека.

Ключевые слова: брак, каноническое право, цели брака, атрибуты брака, церковная юрисдикция 
